\title{
O ESPAÇO FICCIONAL NO CONTO “O POÇO E O PÊNDULO”, DE EDGAR ALLAN POE
}

\author{
Cristina Rothier Duarte ${ }^{1}$ \\ Jaine de Sousa Barbosa ${ }^{2}$
}

RESUMO: Nas narrativas literárias, o espaço ficcional constitui uma categoria analítica que apresenta uma grande importância, pois é por meio dele que se desenvolvem as ações que compõem o enredo. Na literatura fantástica, o espaço ganha uma importância ainda maior, de modo que os autores que se dedicam a esse gênero emprenham-se em trazer em minúcias de detalhes esse elemento, permitindo uma ambientação coerente aos efeitos que deseja provocar. O presente artigo, assim, tem como objetivo analisar como é construída categoria espaço no conto "O poço e o pêndulo", de Edgar Alan Poe [1848]/(2008). A metodologia adotada foi a pesquisa bibliográfica de cunho qualitativo-interpretativo. A partir da leitura do aporte teórico que trata do espaço ficcional, descrevemos e analisamos a construção dos espaços em que a narrativa se desenrola, bem como a influência que eles exercem nas personagens e na trama como um todo.

PALAVRAS-CHAVE: Literatura fantástica; Espaço ficcional; Edgar Allan Poe; O poço e o pêndulo.

\section{INTRODUÇÃO}

Muitas são as categorias que compõem as narrativas fantásticas, assim como os elementos que formam os textos que fazem parte do gênero. Além de aspectos temáticos, como a presença do medo, a indistinção do real e do imaginário e o estranhamento que uma leitura pode causar em quem a realiza, sua estrutura e suas categorias são essenciais, para que se atinja um determinado fim, quando o assunto é narrativa fantástica.

Assim como as demais, a história fantástica também acontece em um determinado período de tempo, com personagens e situações que se desenrolam ao longo do texto e em um espaço que atua como parte fundamental para o desenvolver da trama. Entre as categorias de análise existentes em uma obra, este foi o escolhido como objeto de pesquisa para o presente artigo, uma vez que ele possui grande importância na construção dos sentidos de uma narrativa literária por ser fundamental para sua desenvoltura.

O espaço constitui um dos elementos de maior significado nas narrativas fantásticas, pois é por meio dele que se desenvolve as ações que compõem o enredo da maioria dos textos que correspondem a esse formato. Além de possibilitar descrições sobre as ambientações em que a história acontece, ele

\footnotetext{
${ }^{1}$ Especialização em Ciências da Linguagem Ênfase em Língua Portuguesa pela Universidade Federal da Paraíba, UFPB. Email: cristinarothier@hotmail.com

${ }^{2}$ Graduada em Letras - Língua Portuguesa pela Universidade Federal de Campina Grande, UFCG. Email: jaine.barbosa_@outlook.com
} 
pode sobrepor dimensões em um mesmo contexto narrativo, uma vez que no texto fantástico as situações se desenrolam em planos que variam entre o real (o mundo em que personagens e leitores estão) e o imaginário, que é modificado ao longo da narrativa pelas dubiedades que envolvem o todo narrativo. E é no desenvolver desta produção que observaremos como isso se dá.

Levando em consideração a importância do espaço ficcional na narrativa fantástica, optamos por eleger essa categoria analítica para o estudo de "O poço e o pêndulo", de Poe. Para tanto, utilizamos como base teórica Santos e Oliveira (2001), Borges Filho (2007), Osman Lins [1924]/ (1976), Yi-fu Tuan (1980), Bachelard (2008), França (2013) e Menon (2013), para explicar e exemplificar como é observada a categoria espaço dentro desse tipo de narrativa.

\section{O ESPAÇO FICCIONAL}

Até pouco tempo, o estudo sobre o espaço ficcional não despertava significativo interesse acadêmico, no entanto, atualmente, essa categoria analítica tem sido objeto de investigação de diversos grupos que se dedicam à sua compreensão e à sua representação na literatura, sobretudo, em escritos que envolvem o Fantástico, o Gótico e o Insólito.

Fazendo uma breve revisão do aporte teórico que trata do espaço como categoria literária, Santos e Oliveira (2001), ao introduzirem seus estudos sobre o tema, criam uma interessante relação entre essa categoria e o ser. Os autores associam o estar em determinado espaço à situação de ser, apontando para a impossibilidade de ser sem estar. E, sob o viés literário, não é diferente, pois "se criamos uma personagem ficcional, vamos posicioná-la relativamente a outros elementos de nosso texto" (2001, p. 67-68), tais como o espaço geográfico (situação física), o espaço histórico (tempo), o espaço social (relação com outros personagens), o espaço psicológico (suas próprias características existenciais) etc.

Como podemos observar a partir das considerações de Santos e Oliveira, o espaço literário não se limita à concepção de espaço físico, compreendido como lugar que apresenta três dimensões - largura, altura e profundidade. Esse espaço, conforme traz Borges Filho (2007), é dotado de um caráter relacional: 
[...] Quando falamos de espaço, referimo-nos tanto aos objetos e suas relações como ao recipiente, isto é, à localização desses mesmos objetos. Além disso, nunca podemos esquecer o observador a partir do qual aquelas relações são construídas na literatura. Assim, ao analisarmos um espaço qualquer, por exemplo, casa, navio, escola etc., não podemos nos esquecer dos objetos que compõem e constituem esse espaço e de suas relações entre si e com as personagens e/ou narrador. Continente, conteúdo e observador são partes integrantes de uma topoanálise, pois é a junção desses três elementos que forma o que se entende por espaço. (BORGES FILHO, 2007, p. 17).

Em suma, "[o] espaço seria composto de cenário, natureza e ambiente." (BORGES FILHO, 2007, p. 22, grifos no original). O cenário, compreendido como o espaço em há a intervenção humana na sua criação, "[g]eralmente, são os espaços onde o ser humano vive. Através da sua cultura, o homem modifica 0 espaço e o constrói a sua imagem e semelhança.", construindo, assim, o que denomina de cenário (BORGES FILHO, 2007, p. 47). A natureza é o espaço em que essa intervenção humana não ocorre, tais como a floresta, o mar, o rio, o lago etc. Por fim, ambiente é definido como "[...] a soma de cenário ou natureza mais a impregnação de um clima psicológico." (BORGES FILHO, 2007, p. 50), portanto, entra na sua composição a participação do personagem e/ou do narrador, mais especificamente a sua psique.

Delimitada a concepção que o espaço ficcional pode assumir em uma obra literária, impende também verificar suas funções, para melhor entendermos como se dá a ação desse elemento literário.

Borges Filho, fazendo a ressalva de que são inúmeros os papéis que o espaço desempenha nas narrativas literárias, destaca sete funções: (a) caracterizar as personagens, situando-as no contexto socioeconômico e psicológico em que vivem; (b) influenciar as personagens e também sofrer suas ações; (c) propiciar a ação; (d) situar a personagem geograficamente; (e) representar os sentimentos vividos pelas personagens; (f) estabelecer contraste com as personagens; $(\mathrm{g})$ antecipar a narrativa.

Vejamos sucintamente cada uma dessas funções ${ }^{3}$ :

A função caracterizadora do personagem, de acordo com Osman Lins (1976), é desempenhada pelo escritor à medida que ele vai situando o personagem na narrativa: "[...] quando indicamos, no espaço - notadamente no

\footnotetext{
${ }^{3}$ Notemos que, nem sempre ou raramente, essas funções apareceram concomitantemente em uma mesma narrativa.
}

Revista de Letras JUÇARA, Caxias - Maranhão, v. 02, n. 01, p. 244 - 262, jul. 2018| 246 
espaço doméstico -, a função de, situando a personagem, informa-nos, mesmo antes que a vejamos em ação, sobre o seu modo de ser." (LINS, 1976, p. 97).

A função influenciadora do personagem se dá, quando na narrativa, o espaço determina as ações dos personagens. Para Candido (2006), espaço é capaz de metamorfosear o personagem, de modo que este, uma vez inserido em determinado espaço, passa a sofrer sua influência de forma determinante ao ponto de sua personalidade ser diretamente afetada.

A função propiciadora da ação, bastante próxima da anterior, mas que com ela não se confunde, é o papel do espaço de favorecer, mas não influenciar a ação do personagem. "A personagem é pressionada por outros fatores a agir de tal maneira, não pelo espaço. Entretanto, ela age de determinada maneira, pois o espaço é favorável a essa ação." (BORGES FILHO, 2007, p. 39).

A função de situação do personagem, segundo Borges Filho (2007) é a função denotativa, ou seja, seu papel é informar onde está o personagem em determinada cena da narrativa.

A função representativa de sentimento do personagem se dá como pano de fundo para o estado psicológico do personagem. Quando verificamos o conceito de ambiente, de acordo com Borges Filho (2007), observamos que esse se constitui do somatório do espaço psicológico com o espaço físico (cenário ou natureza), a função representativa de sentimento do personagem, assim, ocorre justamente nesse espaço físico que contextualiza a experienciação psicológica do personagem. Segundo o teórico, são espaços transitórios, espaços que não são aqueles próprios do personagem, mas de passagem.

A função estabelecedora de contraste com o personagem ocorre, quando o espaço não estabelece uma harmonia com os fatos e sentimentos vivenciados pelo personagem, isto é, "não há nenhuma relação entre sentimento da personagem e espaço." (BORGES FILHO, 2007, p. 41).

A função antecipadora da narrativa é o que Borges Filho denomina de prolepse espacial, que se caracteriza pela apresentação de "índices impregnados no espaço", por meio dos quais "o leitor atento percebe os caminhos seguintes da narrativa." (2007, p. 41).

No âmbito do ambiente ficcional, dois outros conceitos caros ao estudo do espaço literário são os de topofobia e topofilia. Intimamente ligados ao elemento 
humano, essas noções referem-se à relação desenvolvida pelo personagem (e/ou narrador) frente ao espaço narrativo.

A topofilia, conceito trabalhado por Yi-fu Tuan (1980), é o amor humano pelo lugar.

[...] A palavra "topofilia" é um neologismo, útil quando pode ser definida em sentido amplo, incluindo todos os laços afetivos dos seres humanos com o meio ambiente material. Estes diferem profundamente em intensidade, sutileza e modo de expressão. A resposta ao meio ambiente pode ser basicamente estética: em seguida, pode variar do efêmero prazer que se tem de uma vista, até a sensação de beleza, igualmente fugaz, mas muito mais intensa, que é subitamente revelada. A resposta pode ser tátil: o deleite ao sentir o ar, água, terra. Mais permanentes e mais difíceis de expressar, são os sentimentos que temos para com um lugar, por ser o lar, o locus de reminiscências e o meio de se ganhar a vida. (TUAN, 1980, p. 107).

$\mathrm{Na}$ literatura, podemos perceber essa relação do personagem com 0 espaço ficcional a partir da descrição realizada pelo autor sobre o contexto espacial e sobre as sensações e ações que esse espaço provoca no personagem. Nesse contexto, Bachelard (2008) dedica-se à abordagem fenomenológica do espaço na poética, entendendo que

[a] topoanálise seria então o estudo psicológico sistemático dos lugares físicos de nossa vida íntima. [...]. Às vezes acreditamos conhecer-nos no tempo, ao passo que se conhece apenas uma série de fixações nos espaços da estabilidade do ser, de um ser que não quer passar no tempo, que no próprio passado, quando vai em busca do tempo perdido, quer "suspender" o voo do tempo. Em seus mil alvéolos, o espaço retém o tempo comprimido. O espaço serve para isso. (BACHELARD, 2008, p. 204).

A fenomenologia do espaço em Bachelard, assim, traduz as sensações motivadas pelo espaço ficcional tomando como ponto partida as memórias que esse espaço desperta. E a topofilia situa-se na esfera do bem-estar que esse espaço proporciona ao homem.

Contrapondo-se à topofilia, temos a topofobia, entendida como a sensação de desconforto e de medo provocada pelo espaço em que nos situamos. De acordo com Yi-fu Tuan [1930]/(2005), o medo é fruto da construção da mente humana, e o termo "paisagens do medo" pode ser empregado tanto para os estados psicológicos, quanto para o espaço real ${ }^{4}$.

\footnotetext{
${ }^{4} \mathrm{O}$ autor fala em "ambiente real", no entanto elegemos o termo "espaço", em consonância com a diferenciação terminológica operada por Oziris Borges Filho, construída em sua obra "Espaço e literatura: introdução à topoanálise".
}

Revista de Letras JUÇARA, Caxias - Maranhão, v. 02, n. 01, p. 244 - 262, jul. 2018 | 248 
[...] $O$ que são paisagens do medo? São as quase infinitas manifestações das forças do caos, naturais e humanas. Sendo as forças que produzem caos onipresentes, as tentativas humanas para controlálas são também onipresentes. De certa forma, toda construção humana - mental ou material - é um componente na paisagem do medo, porque existe para controlar o caos. (TUAN, 2005, p. 12).

Levando o conceito de Yi-fu Tuan para literatura, mais precisamente para a categoria a que nos dedicamos neste artigo, as paisagens do medo podem ser consideradas como aquelas correspondentes ao cenário, à natureza e ao ambiente literários que atravessam o medo, esfera em que nos debruçaremos na seção seguinte.

\section{O ESPAÇO FICCIONAL NA LITERATURA FANTÁSTICA}

É significativa a ação que o espaço exerce sobre nós, quando tratamos da hesitação ou do medo, tendo em vista que esse elemento contribui fortemente para a acentuação e o agravamento de estados de incerteza que são imanentes ao homem no momento em que se vê diante do desconhecido, do incerto.

$\mathrm{Na}$ literatura fantástica, o espaço conferirá ao acontecimento o teor de apreensão necessário para a criação de uma atmosfera de tensão que deve permear essa narrativa, e será ele que intensificará a monstruosidade dos elementos sobrenaturais. Mas não apenas isso, segundo Gama-Khalil "o fantástico se revela [...] por uma estratégia que alça o espaço como desencadeador da hesitação ou da ambiguidade" (2012, p. 33, apud OLIVEIRA, 2016, p. 129). Assim, o espaço contribuirá para a suscitação, no personagem, da dúvida sobre os acontecimentos e sobre os elementos que constroem aquilo que se encontra na zona fronteiriça entre o sobrenatural e o ilusório. É que vemos no exemplo seguinte:

[...] E o edifício? Que curiosa construção! Eu o considerava como um verdadeiro palácio encantado! Era um nunca acabar desvãos. De divisões incompreensíveis. Dificilmente se poderia dizer quando nos encontrávamos no primeiro ou no segundo andar. De compartimento para compartimento, sempre havia degraus a subir ou a descer. Além disso, as divisões laterais eram inúmeras, sem razão de ser, com tantas e reviravoltas que a ideia que fazíamos do conjunto do edifício se aproximava da que fazíamos do infinito. Vivi ali durante cinco anos, nunca consegui determinar com exatidão o pequeno dormitório que ocupava com mais dezoito ou vinte colegas (POE, 2008, p. 237). 
Nessa passagem do conto "Willian Wilson", de Poe, notamos que o evento fantástico ainda não foi introduzido na narrativa, no entanto a descrição do espaço ficcional já insere o personagem no clima de imprecisão e conduz o leitor pelo caminho da incerteza, percurso esse confirmado, no decorrer da história, por meio de acontecimentos dúbios que acarretam um desfecho também ambíguo do conto, momento em que o protagonista é incapaz de reconhecer o espaço em que se situa, bem como é incapaz de reconhecer a si e a seu algoz:

[...] Nesse instante, ouvi mexer na fechadura da porta. Rapidamente, tratei de impedir a importuna entrada de alguém e, em seguida, voltei para junto de meu inimigo agonizante. Ah, só então senti como a linguagem humana é importante para exprimir o espanto e o horror que experimentei perante o espetáculo que me deparou! Durante o curto momento em que me afastara, o aposento mudara completamente em suas disposições! No lugar onde momentos antes eu nada vira, havia um grande espelho (pelo menos assim me pareceu, em minha exaltação). Aproximei-me dele cheio de terror e vi caminhar para mim a minha própria imagem, com o rosto extremamente pálido e todo salpicado de sangue, avançando com passos lentos e vacilantes. (POE, 2008, p. 253).

O espaço, desse modo, se enlaça à imprecisão necessária para estabelecimento da ambiguidade própria das narrativas fantásticas, a fim de impregnar o clima psicológico de tensão e, muitas vezes, medo. Ele possui grande relevância na construção dos sentidos da narrativa, uma vez que o desenvolvimento das ações das personagens só pode ser possível por meio de uma localização que as dê suporte.

No que diz respeito aos gêneros discursivos, presentes nos contos fantásticos, França (2013) explica que essas narrativas são construídas descritivamente.

[...] Em termos de gêneros discursivos, é algo construído, fundamentalmente, por descrições, ou seja, por trechos não-narrativos de uma narrativa. A descrição, todavia, tem um grande impacto nos efeitos estéticos e ideológicos de uma história (BAL, 2007, p. 35). O ambiente não apenas emoldura os personagens e suas ações, mas também é uma fonte de significado e valor. Para o leitor de literatura, as passagens descritivas realizam, com palavras, o modo pelo qual 0 mundo narrado é visto por aquele que narra. [...] Na literatura do medo, as descrições espaciais quase nunca pretendem ser meramente referenciais. Pelo contrário, costumam vir acompanhadas de adjetivações que não apenas informam o leitor sobre as características físicas, sensorialmente perceptíveis, dos locais, mas também contribuem para persuadir o leitor dos perigos inerentes àquele lugar. (FRANÇA, 2013, p. 67). 
Castelos, casarões, florestas são espaços comuns nessa literatura, contudo a forma como são descritos e adjetivados irá fazer emergir o ambiente ameaçador. Então, não teremos apenas um casarão, mas um casarão antigo, pouco iluminado, com paredes descascadas pelo efeito do tempo e da umidade, que impregna todo $\mathrm{o}$ ar com seu mofo. Portanto, sempre uma sucessão de detalhes será elencada para que seja desencadeado o clima sombrio e inóspito, mas propício para a realização de horripilantes eventos.

No tocante aos personagens, Menon (2013) entende que "[f]rente à arquitetura do lugar, as personagens funcionam como joguetes, títeres do próprio espaço que não proporciona saída.", por exemplo:

[...] A aldeia está situada num vale perfeitamente circular, com cerca de quatrocentos metros de circunferência, e é inteiramente cercada de gentis colinas, cujos cumes os habitantes do condado jamais se aventuraram ainda a ultrapassar, dando como razão excelente e suficiente não haver absolutamente coisa alguma do outro lado. (POE, 2008, p. 147).

Como podemos perceber, mediante esse pequeno trecho de "O diabo no campanário", a aldeia protagonista do conto de Poe confina seus habitantes em sua circunscrição aparentemente normal e solícita, não fosse o estranho fato de tudo nela ser rigorosamente igual e sincrônico: casas, jardins, roupas dos moradores, hábitos, enfim, tudo idêntico ao ponto de causar desconforto no leitor.

Conforme veremos mais adiante, o mesmo se dá no conto "O poço e o pêndulo". As ações do personagem são guiadas pelo espaço, de maneira que o mesmo não constitui apenas a situação de onde está o protagonista e a partir de onde se desenrola o enredo. $O$ espaço assume uma importância vital para a sucessão dos eventos da narrativa e para a própria existência do conto.

\section{“O POÇO E O PÊNDULO" E O ESPAÇO FECHADO EDIFICADO EM EDGAR ALLAN POE}

Dado o relevo que os contos de Allan Poe atribuem à categoria analítica espaço, propomos, na presente seção, a análise de representações espaciais exibidas no conto "O poço e o pêndulo" contido na obra Histórias Extraordinárias (1848). 
O espaço, nos escritos fantásticos de Poe, é milimetricamente pensado. No seu ensaio Filosofia da composição [1846]/(1999), em determinado momento, pondera sobre a necessidade de criar, em $O$ corvo, um espaço adequado para produzir os efeitos que pretendia provocar:

[...] O ponto seguinte, a ser considerado, era o modo de juntar o amante e o Corvo: e o primeiro ramo dessa consideração era o local. Para isso, a sugestão mais natural seria a de uma floresta, ou a dos campos; mas sempre me pareceu que uma circunscrição fechada do espaço é absolutamente necessária para o efeito do incidente insulado e tem a força de uma moldura para um quadro. Tem indiscutível força moral para conservar concentrada a atenção e, naturalmente, não deve ser confundida com a mera unidade de lugar.

Determinei, então, colocar o amante em seu quarto - num quarto para ele sagrado, pela recordação daquela que o frequentara. O quarto é apresentado como ricamente mobiliado, isso na simples continuação das ideias, que eu já tinha explanado, a respeito da Beleza como a única verdadeira tese poética. (POE, (1999, on-line).

Como não poderia ser diferente em "O poço e o pêndulo", Poe se utiliza novamente do espaço fechado recorrendo, analogicamente, à função que the atribuiu em $O$ corvo, que, segundo Gama-Khalil, tem o intuito "[...] de gerar o sentido de isolamento, não só pela temática engendrada como pelo espaço onde o evento acontece, enquadrando a cena." (2012, p. 35).

De fato, em uma cenografia de repressão, já que "O poço e o pêndulo" se dá no contexto da Inquisição espanhola, o espaço ficcional, em que um sentenciado experiencia todas as angústias de uma expiação, não poderia ser outro que um claustro, um espaço mínimo de encarceramento, manifestação da tirania e da coercitividade engendrada por aqueles que detêm o poder, controlam a lei e decidem sobre o destino das pessoas que os desafiam.

Antes de adentrarmos na análise do espaço ficcional de "O poço e o pêndulo", é importante, ab initio, notarmos que Poe se utiliza da inominação do espaço, para Ihe atribuir efeitos particulares como a incerteza e a tensão. Além disso, no conto, essa estratégia narrativa desencadeia uma disputa travada entre o espaço e o personagem, em que este, levantando uma série de hipóteses sobre aquele (calabouço? túmulo?), espera dominá-lo, descobrindo onde está e, consequentemente quem ele, personagem, é.

O conto se inicia com o narrador autodiegético, o prisioneiro, descrevendo sua exaustão e o misto de sensações que precedem o desmaio sofrido logo após a sentença a que é submetido. Esse primeiro espaço da narrativa, embora não 
seja nomeado, é conhecido pelo prisioneiro, que dá pistas ao leitor sugestionando uma espécie tribunal, devido à presença de juízes que prolataram a sua sentença.

Quando retorna a si, o protagonista está em um segundo espaço - um espaço de transição, também inominado e impreciso tanto para ele, quanto para o leitor. Ele está sendo transportado e, entre as inúmeras lembranças e/ou fantasias que o envolveram durante o sono (in)consciente - ele mesmo deixa em dúvida o seu estado-, se recorda de ter a sensação de estar sendo conduzido para baixo: "Essas sombras de memória falam indistintamente de altas figuras que se erguiam e me arrastavam em silêncio... para baixo, cada vez mais baixo, até que uma odiosa vertigem me oprimiu à simples ideia daquela descida interminável." (POE, 2008, p. 111).

No momento em que abre os olhos - fato que o leitor somente percebe, quando cessa a sua transferência de onde fora julgado para onde se encontra -, sem novamente nomear o espaço em que encontra, o prisioneiro estica a mão, a fim de tentar reconhecer o lugar e de compreender quem ele mesmo é: "Estiquei a mão, e ela caiu pesadamente sobre algo úmido e duro. Deixei que ela ali ficasse alguns minutos, enquanto me esforçava por descobrir onde poderia estar e o que eu poderia ser." (POE, 2008, p. 112).

Poe, aqui, deixa claro que o espaço determinará a existência do prisioneiro, no sentido de que o ser estará adstrito ao estar. Seria ele um homem livre, um prisioneiro ou mesmo um cadáver? Tudo dependeria de onde estivesse. Todavia, seu temor de nada encontrar ao abrir os olhos se confirma. O espaço, até então inominado, se caracteriza predominantemente pela escuridão e pelo confinamento: "O negror da noite eterna rodava-me. Esforcei-me por respirar. A intensidade das trevas parecia oprimir-me e sufocar-me. A atmosfera estava intoleravelmente confinada." (POE, 2008, p. 112).

Então, nesse terceiro espaço da narrativa, o prisioneiro, percebendo que está encarcerado, decide explorar onde se encontra para compreender esse espaço incerto, nomeá-lo e dominá-lo:

[...]A agonia da incerteza tornou-se, afinal intolerável e, com cautela, movi-me para diante, com os braços estendidos, os olhos saltando-me das órbitas, na esperança de apanhar algum débil raio de luz. Dei vários espaços, mas tudo era ainda escuridão e vazio. Respirei mais livremente. Parecia evidente que minha sorte não era, pelo menos, a mais odiosa das mortes. (POE, 2008, p. 113). 
Momentaneamente, o prisioneiro sente-se aliviado em razão das impressões que teve ao investigar o recinto, no entanto o horror torna a the dominar dadas às lembranças do que havia ouvido falar sobre os calabouços de Toledo. "Naturalmente, as pessoas tinham motivo para temer a prisão: coisas horríveis aconteciam atrás de suas paredes." (TUAN, 2005, p. 311). Ademais, era um condenado da Inquisição. A morte lenta e cruel, assim, era certa, apenas não conhecia a forma e quando se daria.

Em nova tentativa de explorar o recinto, o prisioneiro cria uma estratégia de, tateando "sua parede tão perfeitamente uniforme" (POE, 2008, p. 114), a partir de um ponto demarcado com um trapo, conseguir compreender o lugar em sua forma e dimensão. O percurso da circunferência, após a interrupção causada por um desmaio, chega a cem passos, porém, devido à grande quantidade de ângulos que a parede tinha, não pôde precisar sua forma.

Como vemos, o prisioneiro é refém do espaço incerto. É este que propicia as suas emoções e suas ações. Conhecedor de seu estado de condenado, poderia passivamente esperar a execução letal, mas o cenário claustrofóbico e de escuridão provocam no prisioneiro a necessidade determinante de deslindar aquele recinto cujo ambiente é de medo.

Decide, então, empreender nova averiguação, agora, atravessando a área de onde estava confinado. "O chão, embora parecesse de material sólido, era traiçoeiro e lodoso." As características, a partir das quais o prisioneiro descreve o solo, revelam a sua incerteza também em relação ao que poderia ser mais estável em um cárcere, a superfície. Parece seguro, mas não é digno de credibilidade. Por isso, inicialmente, usa da cautela para a exploração, mas depois caminha com firmeza, até que sofre uma queda decorrente de suas pernas terem se enroscado em um tecido de sua roupa. A queda, contudo, poupa-Ihe da morte, pois a poucos centímetros há um poço, cuja profundidade não podia precisar.

O poço, dentro da narrativa, representa um microespaço conhecido pelo prisioneiro apenas por meio das histórias que considerava fabulosas e absurdas sobre a Inquisição. Naquele momento, então, ele tem a certeza de que sua morte, premeditada pelos inquisidores como cruel e horrenda, estava associada àquele 
espaço, seu algoz. A sensação de incerteza provocada pelo espaço, então, é substituída pela topofobia:

[...] Para as vítimas de sua tirania, havia a escolha da morte por meio das mais cruéis agonias físicas, ou da morte mediante os mais odiosos horrores morais. Eu havia sido reservado para esta última. O longo sofrimento tinha relaxado meus nervos, a ponto de eu tremer ao som de minha própria voz e me tornar, sob todos os aspectos, material apropriado para as espécies de tortura que me aguardavam. Com os membros todos trêmulos, tateei meu caminho de volta à parede, resolvida ali perecer antes que arriscar-me aos terrores dos poços, que imaginação agora desdobrava em muitos, espalhados em todas direções, no calabouço. (POE, 2008, p. 115-116, grifos nossos).

O espaço agora nominado - era, enfim, um calabouço - se apresenta como um ambiente de total ameaça para o prisioneiro. Para os condenados à morte, a execução geralmente se encontra fora do cárcere, mas, no seu caso, o perigo era iminente mesmo no interior da sua cela.

Interessante notar que, a cada elemento novo relativo ao espaço que aparece no conto, o personagem encontra-se em estado letárgico, acabando de acordar de desmaios ou de sonos induzidos por substâncias. De maneira que ao leitor não é conferido o poder da certeza, é, portanto, na fronteira entre o real e imaginário que ele caminha. Acerca desse elemento estético da literatura fantástica, esclarece Gama-Khalil remetendo-se a Furtado (1980):

[...] o espaço construído pela literatura fantástica é essencialmente híbrido: "os diversos elementos que contribuem para a representação do espaço fantástico polarizam-se em dois tipos de cenário cujos componentes, por sua vez, se intercambiam frequentemente": o cenário realista e o cenário alucinante, e é o jogo entre esses dois cenários que fará com que a narrativa desenvolva uma fenomenologia insólita. (GAMA-KHALIL, 2012, p. 34).

Assim, o novo espaço que lhe é revelado surge logo após a recuperação de mais um sono. Ao acordar, está tudo iluminado por uma "luz viva e sulfúrea" (POE, 2008, p. 116), e, então, percebe seu erro quanto à dimensão do lugar. $O$ perímetro do recinto não era maior que vinte cinco metros, e sua forma era quadrada, com algumas depressões ou nichos, fato que, acrescentado à escuridão completa e ao estado letárgico do prisioneiro, confundira os parcos sentidos que este dispunha para o exame da cela. Além disso, a parede do calabouço não era de alvenaria, mas de chapas de algum metal, e dotada de 
pinturas horrendas de demônios; o chão era de pedra; e, no centro, havia um único poço.

Conhecer a descrição em detalhes de onde se encontra é de tamanha importância para o personagem-narrador que o relato acerca da sua situação deitado de costas, amarrado a uma armação de madeira próxima do chão - fica para um momento posterior e logo é interrompido para retornar ao detalhamento da prisão e, consequentemente, do prosseguimento da execução da pena.

A cela tinha mais de dez metros de altura, e, no teto, havia uma representação clássica do Tempo, sendo que, no lugar da foice, havia um pêndulo, que se movia, baixando-se em direção do prisioneiro imobilizado junto à armação de madeira a que estava atado:

\begin{abstract}
Olhando para cima, examinei o teto de minha prisão. Tinha uns dez ou doze metros de altura e era construído de madeira idêntica à das paredes laterais. Em um de seus painéis, uma figura bastante singular absorveu-me toda a atenção. Era a pintura do Tempo, tal como é comumente representado, solvo por, em lugar de uma foice, segurar ele aquilo que, a uma olhada casual, supus ser o desenho de um enorme pêndulo, como os que vemos nos relógios antigos. Contudo, havia algo na aparência daquela máquina que me levou a olhá-la mais atentamente. [...] (POE, 2008, p. 118).
\end{abstract}

A inserção desse outro objeto na narrativa cria um novo cenário. Antes havia um calabouço desconhecido dotado da possibilidade de múltiplos poços em meio a escuridão. Agora, iluminada, a cela, percebida em todos os detalhes pelo prisioneiro, apresenta um perigo vindo de cima. Embora o cenário seja diverso, o ambiente de medo e tensão permanecem como antes.

Nesse cenário recente, a morte continua iminente, mas os executores não têm pressa para a consumar a sanção fatal. A cadência do pêndulo é acompanhada por uma aproximação lenta e psicologicamente cruel em direção ao corpo do prisioneiro. Não basta aos executores tirarem-lhe a vida, ele tem que padecer todos os terrores possíveis provocados pelo ambiente antes de efetiva execução da pena - a morte. Um desses terrores é a presença de inúmeros ratos atraídos pelo cheiro de uma carne salgada colocada pelos inquisidores, possivelmente a ação não partiu da necessidade completa de alimentá-lo, mas de atrair os bichos do poço para a sela.

Um leve ruído atraiu-me a atenção e, olhando para o chão, vi vários ratos enormes atravessando-o. Haviam saído do poço, que se achava 
bem à vista, à minha direita. No momento mesmo em que os observava, subiram aos bandos, apressadamente e com olhos vorazes, atraídos pelo cheiro da carne. Por isso, era preciso muito esforço e atenção para afugentá-los. (POE, 2008, p. 118).

Não bastava a luta para afugentar os animais, algo agora pior é percebido pelo prisioneiro. O espaço em que estava inserido lhe traz um mais novo sofrimento. A morte se aproximava, e cada novo desafio vivenciado dentro da cela precisa impulsioná-lo a escapar, embora a situação em que se encontrava não demonstrasse possibilidades para tanto. Com a modificação no oscilar do pêndulo, era cada vez mais real a sensação de que o personagem seria engolido pelo pêndulo, pelo poço, pelos ratos e pela própria inquisição.

[...] O balanço do pêndulo havia aumentado de quase um metro em extensão. Como consequência natural, sua velocidade era, também, muito maior. Mas o que mais me perturbou foi a ideia de que ele havia imperceptivelmente descido. Observei agora - e com que horror, é desnecessário dizê-lo - que sua extremidade inferior era formada por um crescente de aço cintilante com certa de trinta centímetros de comprimento, de ponta a ponta; essas pontas voltavam-se para cima, e o gume de baixo era evidentemente tão afiado quanto o de uma navalha. Também como uma navalha, parecia pesado e maciço, estendendo-se para cima, a começar do gume, numa sólida e larga estrutura. Estava ligado a uma pesada haste de bronze, e o conjunto assoviava ao balançar-se no ar. (POE, 2008, p. 118-119, grifos no original).

Depois de todo o drama psicológico e físico que é descrito no decorrer da narrativa, mais adiante, o prisioneiro é invadido pela esperança, então arquiteta uma forma de escapar, aproveitando-se do estado insalubre do recinto. Besunta as cordas que o prendem com os restos de carne gordurosa alcançados no chão, para que os ratos, que partilham com ele o mesmo espaço, roam-na, o que funciona. Ao escapar, o pêndulo para e é suspenso. No entanto, outro problema se põe à sua frente. Agora, todo o espaço da cela começa a sofrer alterações fortemente perceptíveis e provenientes do fogo que começava a incendiar o local, o que causa na personagem não somente o medo, mas alucinações:

[...] Era óbvio que qualquer coisa de incomum, certa mudança que, a princípio, não pude perceber distintamente, tinha ocorrida no aposento. Durante vários minutos de sonhadora e trêmula abstração, perdi-me em vãs e desconexas conjecturas. Nesse período, dei-me pela primeira vez da origem da luz sulfurosa que iluminava a cela. Vinha de uma fenda de cerca de um centímetro e meio de largura que se estendia ao redor de toda a prisão, na base das paredes, que assim pareciam, e o eram de fato, inteiramente afastadas do solo. Tentei, sem dúvida inutilmente, olhar por essa abertura.

Ao erguer-me da tentativa, o mistério do aposento logo se impôs à minha compreensão. Observei que, embora os contornos das figuras nas 
paredes fossem suficientemente distintos, suas cores pareciam manchadas e indefinidas. Essas cores tinham agora adquirido, e o estavam adquirindo, um brilho assustador e muito intenso, que dava às espectrais e diabólicas imagens um aspecto capaz de fazer tremerem nervos até mais firmes que os meus. Olhos de demônio, de vivacidade selvagem e sinistra, contemplavam-me, vindos de mil direções onde antes nenhum fora visível, e eles cintilavam com o lívido clarão de um fogo que eu não podia forçar a imaginação a considerar irreal. (POE, 2008, p. 123-124).

A cela de metal começa a derreter em decorrência de um incêndio que se dá a partir do lado de fora, deixando de ser quadrada e assumindo a forma de um losango. A ameaça estável ostentada pelo pêndulo, cuja trajetória era constante e regular, desaparece. Agora, o perigo vem flamejante de todos os lados. O espaço deixa de ser uma clausura e passa a ser uma armadilha, encurralando-o: a única e última alternativa que lhe resta é dar cumprimento à execução inaugural, jogarse no poço, o que não se dá em razão da tomada da prisão pelo exército francês.

\begin{abstract}
O calor aumentava com rapidez e ainda uma vez olhei para cima, a tremer como num acesso de febre. Segunda alteração tinha se verificado na cela, e agora a mudança era evidentemente na forma. Como antes, foi em vão que tentei, a princípio, perceber ou compreender o que estava ocorrendo. Mas não me foi dado permanecer em dúvida por muito tempo. A vingança inquisitorial fora apressada por minha dupla fuga, e não havia mais possibilidade de negacear o Rei dos Terrores. O quarto fora quadrado. Notei que dois de seus ângulos de ferro eram agora agudos e dois, consequentemente, obtusos. A terrível diferença aumentava velozmente, com um ruído lamentoso e surdo. Em um instante, o aposento trocara sua forma pela de um losango. (POE, 2008, p. 124-125).
\end{abstract}

O novo formato da cela, que impulsionava o prisioneiro a jogar-se no poço, o faz perceber que este era o desejo de seus adversários desde o princípio. A cada passo dado, a distância entre ele o profundo buraco no local em que estava se fazia menor e isso só Ihe dava uma única alternativa, lançar-se à escuridão.

Fugi - mas, fechando-se, as paredes impeliam-me irresistivelmente para diante. Afinal, de meu corpo queimado e torcido, separavam-me não mais que dois centímetros de solo firme do soalho da prisão. Não lutei mais; a agonia de minha alma, porém, exalou-se num grito alto, longo e decisivo de desespero. Senti que oscilava sobre a borda... Desviei os olhos... (POE, 2008, p. 125).

Seu fim parece certo, até que o desfecho da narrativa é modificado por uma voz humana e sons de trombeta que trazem a notícia de que a Inquisição 
estava nas mãos de seus inimigos. O prisioneiro é puxado para fora do poço e salvo por um General.

Pelas passagens que pontuamos neste trabalho, percebemos que a estética de Poe na criação do espaço ficcional é determinante para o efeito catártico provocado no leitor. O espaço inominado, incerto, mas minimamente pensado, transmite-nos as sensações do claustro - o medo, a tensão, o asco advindo do recinto de cumprimento da pena - criando um ambiente de morte iminente, de intensa insegurança, enfim, de tortura psicológica. Mas não apenas isso, Poe edifica um espaço situado na fronteira entre o real e o imaginário. As constantes metamorfoses, que o espaço sofre no decorrer da narrativa, e a construção objetos insólitos, que suscitam modalidades insólitas de penas de morte, despertam dúvidas no leitor, quando tais fatos são somados aos reiterados estados de letargia do narrador autodiegético.

O espaço ficcional de "O poço e o pêndulo", em suma, constitui uma categoria analítica tão importante quanto o personagem. Uma vez que produz ações próprias e provoca as ações do prisioneiro, fazendo toda a narrativa girar em torno de si, o espaço protagoniza o conto com a colaboração do personagem principal.

\section{CONCLUSÃO}

Analisar e descrever o espaço em que uma narrativa acontece não é somente observar onde a história se passa, mas mergulhar nela por meio de suas descrições, principalmente quando se trata de literatura fantástica, cujo objetivo é causar estranhamento no leitor e lhe suscitar as maiores dúvidas, uma vez que o real e imaginário se misturam entre as incertezas, os desconfortos e a ausência de respostas para o que vai acontecer no decorrer da trama.

Neste artigo, buscamos analisar a construção da categoria espaço no conto "O poço e o pêndulo" contido na obra Histórias Extraordinárias (1848), de Edgar Alan Poe. O conto selecionado para o estudo traz um espaço extremamente relevante à construção do texto, isso se dá porque toda problemática enfrentada pelo protagonista acontece em um macroespaço, que se fragmenta em outros espaços. Inicialmente ele é caracterizado como um obstáculo sólido, uma parede que parecia uma pedra lisa, úmida e fria, com chão 
escorregadio. O personagem, depois de muito tempo de indeterminação, finalmente, o denomina de calabouço.

É nesse lugar que a trama se desenrola e aflige o homem de modos diversos. Na tentativa de conhecer o local em que estava, ele se depara com um poço dentro do calabouço, e percebe que era uma armadilha para sua morte. Com a cabeça na borda, ele sente um vapor pegajoso que viria das profundezas do lugar. Em outro momento, sendo observado por uma força invisível (como ele denomina), e que acompanhava suas formas de escapar da morte, o homem é colocado em outro perigo: é amarrado e vê um pêndulo que o atingiria a qualquer momento. No entanto, assim como da primeira vez, encontra saída e percebe que pode se livrar da pena que o esperava. Consegue escapar das cordas que 0 prendem graças aos ratos que as roem, mas, novamente, vê-se prestes a morrer, porque a prisão passa a flamejar e ir ao encontro do poço seria sua única saída. No entanto, para sua sorte, a situação é modificada ao ouvir ruídos de vozes humanas! E o som vibrante de muitas trombetas. As paredes de fogo recuaram, e um braço estendido o puxou, enquanto estava prestes a cair no abismo. Era o braço do General Lassalle que, junto com o exército francês, entrara em Toledo.

Como vemos, o prisioneiro é refém de um espaço incerto e que governa suas emoções e suas ações. Embora soubesse da condenação, que o poderia deixar inerte, por ser irreversível, ele é levado pelo cenário claustrofóbico e de escuridão que o provoca a necessidade determinante de abandonar o lugar de qualquer forma. O conto, como um todo, nos leva às mesmas sensações lancinantes pelas quais passa o protagonista em sua luta pela sobrevivência e nos mostra como pode estar estruturada uma narrativa que é fantástica não só por obedecer às características propostas pelo gênero, mas por nos encantar em toda sua singularidade desesperadora.

\section{THE FICTIONAL SPACE IN THE SHORT STORY "THE PIT AND THE PENDULUM”, BY EDGAR ALLAN POE}

\footnotetext{
ABSTRACT: In literary narratives, fictional space is an analytical category that has a great importance, because it is through it that it develops as actions that make up the plot. In fantastic literature, space becomes even more important, so that authors who dedicate themselves to this genre undertake to bring in detail details of this element, allowing a coherent setting to the effects it wishes to provoke. This article, therefore, aims to analyze how space category is constructed in
} 
Edgar Alan Poe's short story "The Well and the Pendulum" [1848] / (2008). The methodology adopted was the qualitative-interpretative bibliographical research. From the reading of the theoretical contribution that deals with the fictional space, we describe and analyze the construction of the spaces in which the narrative unfolds, as well as the influence they exert on the characters and the plot as a whole.

KEYWORDS: Fantastic literature; Fictional space; Edgar Allan Poe; The pit and the pendulum.

\section{REFERÊNCIAS}

BACHELARD, Gaston. A Poética do Espaço. São Paulo: Martins Fontes, 2008.

BORGES FILHO, Ozíris. Espaço e literatura: introdução à topoanálise. Franca: Ribeirão gráfica e Editora, 2007.

CANDIDO, Antonio. Degradação do Espaço: estudo sobre a correlação funcional dos ambientes, das coisas e do comportamento em L'Assommoir. Revista de Letras, São Paulo, UNESP, v. XLVI, n. 1, p. 29-61, jan./jun. 2006.

FRANÇA, Júlio. "A alma encantadora das ruas" e "Dentro da noite": João do Rio e o medo urbano na literatura brasileira. In: GRACÍA, Flávio; FRANÇA, Júlio; PINTO, Marcello de Oliveira (org). As arquiteturas do medo e o insólito ficcional. Rio de Janeiro: Editora Caetés, 2013. p. 66-78.

GAMA-KHALIL, Marisa Martins. As teorias do fantástico e a sua relação com a construção do espaço ficcional. In: GARCIA, Flávio; BATALHA, Maria Cristina. Vertentes teóricas e ficcionais do insólito. Rio de Janeiro: Editora Caetés, 2012, p. 30-38.

LINS, Osman. Lima Barreto e o espaço romanesco. São Paulo: Ática, 1976.

MENON, Maurício Cesar. Espaços do medo na literatura brasileira. In: GRACÍA, Flávio; FRANÇA, Júlio; PINTO, Marcello de Oliveira (org). As arquiteturas do medo e o insólito ficcional. Rio de Janeiro: Editora Caetés, 2013. p. 79-91.

OLIVEIRA, Bruno Silva de; GAMA-KHALIL, Marisa Martins. O espaço como elemento irradiador do medo na literatura sertanista de Afonso Arinos e Bernardo Guimarães. Revista Abusões, Rio de Janeiro, UERJ, v. II, n. 2, p. 127-153, jan./jun. 2016.

POE, Edgar Allan. Histórias extraordinárias. Tradução de José Paulo Paes. São Paulo: Companhia das Letras, 2008.

Filosofia da composição. Poemas e ensaios. Tradução de Oscar Mendes e Milton Amado. 3 ed. revista São Paulo: Globo, 1999.

SANTOS, Luis Alberto Brandão; OLIVEIRA, Silvana Pessôa de Oliveira. Sujeito, Tempo e Espaço ficcionais: introdução à teoria da literatura. São Paulo: Martins Fontes, 2001. 
TUAN, Yi-fu. Topofilia: um estudo da percepção, atitudes e valores do meio ambiente. São Paulo: Difel, 1980.

. Paisagens do medo. São Paulo: Editora da UNESP, 2005.

Data da Submissão: 16/04/2018

Data da Aprovação: 24/07/2018

Revista de Letras JUÇARA, Caxias - Maranhão, v. 02, n. 01, p. 244 - 262, jul. 2018 | 262 